\title{
Biogenic amine regulation of bovine luteal progesterone production in vivo*
}

\author{
P. J. Battista, J. P. Poff, D. R. Deaver† and W. A. Condon \\ Department of Animal and Nutritional Sciences, The University of New Hampshire, Durham, \\ New Hampshire 03824, and $\nmid$ Dairy Breeding Research Center, Pennsylvania State University, \\ University Park, Pennsylvania 16802, U.S.A.
}

\begin{abstract}
Summary. Biogenic amines were administered using osmotic pumps placed subcutaneously in the neck region of regularly cycling, non-lactating dairy cows on Days 9-11 (oestrus = Day 0) of the oestrous cycle. Blood samples were collected using indwelling jugular catheters and the plasma progesterone concentrations were measured. Samples were collected at 4- $\mathrm{h}$ intervals for the first $12 \mathrm{~h}$ of treatment and thereafter at 12 -h intervals for the remainder of the 72 -h treatment period. After administration of various doses of noradrenalne, adrenaline and serotonin $(0.5-2.0 \mu \mathrm{g} /$ $\mathrm{kg} / \mathrm{h}$ ) significant elevation of plasma progesterone was achieved at a dosage of $2 \cdot 0 \mu \mathrm{g} / \mathrm{kg} / \mathrm{h}(P<0.01)$. The response to adrenaline was greater than that observed for noradrenaline and serotonin $(P<0.05)$. Within-treatment comparison to pretreatment samples showed plasma progesterone concentrations to increase within $4 \mathrm{~h}$ after the administration of noradrenaline, adrenaline and serotonin $(P<0.05)$ and this enhancement was maintained throughout the treatment period $(P<0 \cdot 05)$. The elevation in plasma progesterone concentrations induced by noradrenaline, adrenaline and serotonin was independent of changes in circulating concentrations of luteinizing hormone. These results support a physiological role for endogenous biogenic amines in the control of bovine luteal progesterone production.
\end{abstract}

\section{Introduction}

The catecholamines, noradrenaline and adrenaline, can regulate the in-vitro biosynthesis of cAMP and progesterone by luteal tissue from a variety of species (cow: Condon \& Black, 1976; Godkin $e t$ al., 1977; Milvae et al., 1983; rat: Harwood et al., 1980; Ratner et al., 1980; Norjavaara et al., 1982; rabbit: Birnbaumer et al., 1976; ewe: Jordan et al., 1978; sow: Perkins et al., 1986). We have reported that the indoleamine serotonin enhances the production of progesterone by bovine luteal cells in vitro (Battista \& Condon, 1986a).

In vivo, the infusion of noradrenaline, adrenaline or the $\beta$-adrenergic agonist isoproterenol elevated plasma progesterone concentrations in the ewe (Bolt \& Rollins, 1976), and infusion of noradrenaline increased cAMP levels in corpora lutea of the rat (Norjavaara et al., 1983). In contrast, in-vivo administration of noradrenaline and isoproterenol was ineffective in regulating progesterone production in oestrous rats, although fenoterol, a $\beta_{2}$-adrenergic agonist, resulted in enhanced progesterone production (Zsolnai et al., 1982). Infusion of adrenaline in early pregnant women increased plasma progesterone (Fylling, 1971a), but these effects may be due to stimulation of placental progesterone production rather than a direct effect on luteal function (Fylling, 1971b; Flint et al., 1974; Csapo \& Herczeg, 1977). This is supported by the observation that human luteal

*Reprint requests to W. A. Condon. 
tissue is refractory to stimulation by exogenous adrenergic agonists in vitro (Richardson \& Masson, 1980; Casper \& Cotterell, 1984).

The infusion of isoproterenol or the $\beta$-adrenergic antagonist propranolol in pseudopregnant rabbits did not alter luteal function (Gadsby et al., 1985). These authors suggested that endogenous catecholamines are not involved in the regulation of luteal steroidogenesis in vivo. The physiological significance, if any, of biogenic amines in the in-vivo regulation of bovine luteal progesterone production is unknown. It was the purpose of this study to determine whether the administration of noradrenaline, adrenaline and serotonin could stimulate the production of progesterone in vivo, as has been observed in vitro.

\section{Materials and Methods}

Experimental procedures. Serotonin, L-noradrenaline and L-adrenaline (Sigma Chemical Co., St Louis, MO) were administered using osmotic pumps (Alza Corp., Palo Alto, CA). Pumps were inserted subcutaneously in the neck region of regularly cycling, non-lactating dairy cows on Days 9-11 of the oestrous cycle (oestrus $=$ Day 0 ) under general (Rompun: Miles Laboratories, Inc., Shawnee, KA) and local (Lidocaine HCl; J.A. Webster, Inc., N. Billerica, MA) anaesthesia. Treatments were prepared in a $0.15 \mathrm{M}-\mathrm{NaCl}$ solution $(\mathrm{pH} 4.0$ ) to deliver controlled release rates of $0.5,1.0$ and $2.0 \mu \mathrm{g} / \mathrm{kg} / \mathrm{h}$. Blood samples were collected using indwelling jugular catheters (Abbocath-T, 14gauge $\times 5.5$ in: Abbot Hospitals, Inc., N. Chicago, IL) and samples were collected at 4-h intervals for the first 12 h of treatment and thereafter at $12-\mathrm{h}$ intervals for the remainder of the 72 -h treatment period. Duplicate pretreatment samples were obtained from each animal by jugular venepuncture before experimental manipulation. Blood samples were transferred to heparinized tubes and placed on ice for transport to the laboratory. Samples were centrifuged $\left(4^{\circ} \mathrm{C}\right)$ for $20 \mathrm{~min}$ at $1500 \mathrm{~g}$ after which the plasma fraction was removed and stored at $-20^{\circ} \mathrm{C}$ until analysed for progesterone and luteinizing hormone (LH).

Progesterone present in plasma samples was quantitated after extraction by radioimmunoassay as previously described (Battista et al., 1984). The progesterone antiserum (No. 337, Niswender) was prepared in sheep against $11 \alpha$-hydroxyprogesterone hemisuccinate conjugated to bovine serum albumin. The progesterone tracer used was $\left[1,2-{ }^{3} \mathrm{H}\right]$ progesterone (New England Nuclear, Boston, MA). The sensitivity of the assay, as determined by the lower $95 \%$ confidence limit of the maximum binding in the absence of any unlabelled progesterone, was $0.07 \mathrm{ng}$. The overall recovery of progesterone extracted from plasma was $92 \pm 1 \cdot 5 \%$. The intra- and interassay coefficients of variability were $5.1 \%$ and $9 \cdot 4 \%$, respectively. All samples from an individual animal were analysed within the same assay and plasma progesterone concentrations are represented as the mean value of duplicate determinations not corrected for recovery. In all cases, $\mathrm{N}$ equals the number of individual animals tested.

To determine the effects of chronic administration of biogenic amines on the release of LH, plasma samples were analysed using a modification of the procedure described by Niswender et al. (1969). Purified ovine LH (LER1056-C2) was radioiodinated using IODO-GEN (1,3,4,6-tetrachloro-3,6-diphenyl-glycouril: Pierce Chemical Co., Rockville, IL). The primary antibody (antiovine LH, GDN-15) was diluted 1:40000 in phosphate-buffered saline $\left(0.14 \mathrm{M}-\mathrm{NaCl}, 0.01 \mathrm{M}-\mathrm{NaPO}_{4}, \mathrm{pH} 7.4\right)$ containing $2 \%$ normal rabbit serum. Second antibody precipitation was achieved using a sheep-anti-rabbit serum (DBRC-1) diluted 1:8 in phosphate-buffered saline. Precipitation of the second antibody complex was facilitated by using $10 \%$ polyethylene glycol. Plasma samples were assayed in duplicates with $100 \mu \mathrm{l}$ plasma. The mean of duplicate values was used for each unknown and all samples were analysed within one assay. The sensitivity of the assay averaged $0.2 \mathrm{ng}$. The minimal detectahle value was used for samples with non-detectable LH concentration. The intra-assay coefficient of variation was $9 \cdot 5 \%$.

Statistical analysis. Differences between treatment means were evaluated using one-way analysis of variance and Student-Newman-Keuls mean separation procedure. Within treatments, differences were determined by using a paired $t$ test.

\section{Results}

The effect of biogenic amines on mean plasma progesterone concentrations over the 72-h treatment period is shown in Table 1 . The administration of noradrenaline, adrenaline and serotonin at 0.5 and $1.0 \mu \mathrm{g} / \mathrm{kg} / \mathrm{h}$ did not significantly alter plasma progesterone concentrations from those observed in animals receiving no treatment $(P>0.05)$. Administration of biogenic amines at $2 \cdot 0 \mu \mathrm{g} / \mathrm{kg} / \mathrm{h}$ significantly elevated circulating concentrations of progesterone above those in untreated animals $(P<0.01)$. The response to adrenaline was greater than that found for noradrenaline and serotonin $(P<0.05)$. The time-course response to biogenic amine stimulation is shown in Fig. 1. Administration of noradrenaline and adrenaline elevated plasma progesterone within 
$4 \mathrm{~h}(P<0.05$, Fig. 1a), and this stimulation was maintained throughout the treatment period $(P<0.05)$. Similarly, treatment with serotonin significantly elevated progesterone within $4 \mathrm{~h}$ $(P<0.05$, Fig. 1b), and this elevation was likewise maintained throughout the 72 -h treatment period $(P<0.05)$.

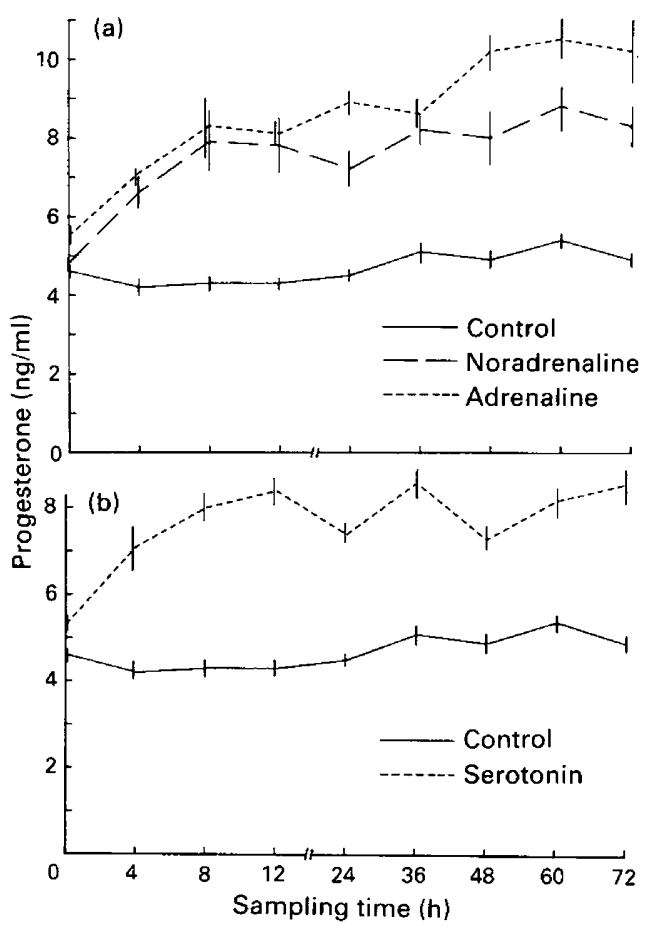

Fig. 1. Time-course effect of (a) noradrenaline, adrenaline and (b) serotonin on the in-vivo stimulation of bovine luteal progesterone production. Values are the mean \pm s.e.m., $N=4$ for noradrenaline, adrenaline and control, $\mathrm{N}=5$ for serotonin. All treatment values are significantly different from corresponding time 0 values $(P<0.05)$.

Table 1. Effect of biogenic amines on mean plasma progesterone concentrations $(\mathrm{ng} / \mathrm{ml})$ over a 72 -h treatment period

\begin{tabular}{lccc}
\hline Biogenic amine & $\begin{array}{c}\text { Conc. } \\
(\mu \mathrm{g} / \mathrm{kg} / \mathrm{h})\end{array}$ & $\begin{array}{c}\text { No. of } \\
\text { cows }\end{array}$ & $\begin{array}{c}\text { Plasma progesterone } \\
(\text { mean } \pm \text { s.e.m. }\end{array}$ \\
\hline Noradrenaline & $0 \cdot 5$ & 2 & $4 \cdot 0 \pm 0 \cdot 37^{\mathrm{a}}$ \\
& $1 \cdot 0$ & 2 & $4 \cdot 8 \pm 0 \cdot 40^{\mathrm{a}}$ \\
Adrenaline & $2 \cdot 0$ & 4 & $7 \cdot 9 \pm 0 \cdot 26^{\mathrm{b}}$ \\
& $0 \cdot 5$ & 2 & $4 \cdot 7 \pm 0 \cdot 60^{\mathrm{a}}$ \\
Serotonin & $1 \cdot 0$ & 2 & $5 \cdot 1 \pm 0 \cdot 62^{\mathrm{a}}$ \\
& $2 \cdot 0$ & 4 & $9 \cdot 0 \pm 0 \cdot 46^{\mathrm{c}}$ \\
None & $0 \cdot 5$ & 2 & $4 \cdot 5 \pm 0 \cdot 17^{\mathrm{a}}$ \\
& $1 \cdot 0$ & 2 & $4.4 \pm 0 \cdot 29^{\mathrm{a}}$ \\
& $2 \cdot 0$ & 5 & $7 \cdot 9 \pm 0 \cdot 23^{\mathrm{b}}$ \\
\end{tabular}

Means with different superscript letters are significantly different $(P<0.01$ for noradrenaline, adrenaline and serotonin $v s$ control; $P<0.05$ for adrenaline $v s$ noradrenaline and serotonin). 
None of the biogenic amines tested significantly altered circulating concentrations of LH. Mean ( \pm s.e.) plasma $\mathrm{LH}$ concentrations over the $72 \mathrm{~h}$ treatment period for noradrenaline, adrenaline, serotonin and control animals were $0.22 \pm 0.11,0.22 \pm 0.12,0.22 \pm 0.11$ and $0.26 \pm 0.13 \mathrm{ng} / \mathrm{ml}$, respectively $(P>0.05)$.

\section{Discussion}

These results demonstrate a role for noradrenaline, adrenaline and serotonin in the in-vivo regulation of bovine luteal progesterone production. None of the biogenic amines tested significantly altered circulating concentrations of $\mathbf{L H}$, suggesting a direct effect of these amines on the corpus luteum. These results are consistent with the finding that none of the biogenic amines used crosses the blood-brain barrier (Axelrod et al., 1959; Douglas, 1970), or significantly alters pituitary LH release under acute conditions (Kamberi \& McCann, 1969; Schneider \& McCann, 1969; Kamberi et al., 1970; Blake, 1976). These results support the in-vitro stimulatory effects of noradrenaline, adrenaline (Condon \& Black, 1976; Godkin et al., 1977; Milvae et al., 1983) and serotonin (Battista \& Condon, 1986a) on bovine luteal progesterone production. The in-vivo enhancement of luteal function by noradrenaline and adrenaline reported in the present study supports previous results obtained in the ewe (Bolt \& Rollins, 1976) and rat (Norjavaara et al., 1983).

Although the mammalian ovary has both adrenergic and cholinergic nerve fibres, the corpus luteum does not appear to be directly innervated by either neural system (Bahr et al., 1974; Burden, 1978; Stefenson et al., 1981). Support for a physiological role of biogenic amines in the regulation of ovarian steroidogenesis is suggested by the finding that electrical stimulation of specific brain regions increased the concentration of oestradiol and progesterone in ovarian venous blood of hypophysectomized-adrenalectomized, pro-oestrous rats (Kawakami et al., 1981). Sectioning of the superior ovarian nerve decreased oestradiol and progesterone concentrations in ovarian venous blood of pro-oestrous rats (Aguado \& Ojeda, 1984) while electrical stimulation of the superior ovarian nerve enhanced luteal progesterone production in dioestrous rats through stimulation of $\beta$-adrenergic receptors (Weiss et al., 1982).

In addition to the absence of direct adrenergic innervation, we have been unable to detect noradrenaline or adrenaline in bovine luteal tissue using HPLC analysis (Battista \& Condon, 1986b), but serotonin was detected (Battista \& Condon, 1986a). Possible sources of luteal serotonin include mast cells, blood platelets, storage of peripherally circulating serotonin or de-novo synthesis. Histological determination of mast cells using Giemsa, toluidene blue and methylene blue staining techniques has failed to demonstrate the presence of mast cells in early or mid-cycle luteal tissue (unpublished observations). Serotonin present in luteal tissue may be derived from peripherally circulating serotonin similar to that reported for rat testicular (Ellis et al., 1972) and adrenal (Verhofstad \& Jonsson, 1983) tissues. We are presently conducting immunohistochemical experiments to examine these possibilities and to determine the cellular location of luteal serotonin. The mechanism whereby biogenic amines regulate bovine luteal progesterone production is unknown. In-vitro studies using rat granulosa cells showed that primary catecholamines increased the enzymic activity of $3 \beta$-hydroxysteroid dehydrogenase while decreasing $20 \alpha$-hydroxysteroid dehydrogenase activity (Hsueh et al., 1983). Ovarian denervation or chemical sympathectomy decreases $3 \beta$-hydroxysteroid dehydrogenase activity in both the interstitial gland and corpus luteum of pregnant rats (Burden \& Lawrence, 1977).

The ability of the primary pathway catecholamines noradrenaline and adrenaline to regulate luteal progesterone production both in vivo and in vitro suggests a physiological role for endogenous adrenergic control of bovine luteal function. Additionally, the ability of serotonin to enhance the production of progesterone in vivo and in vitro and the presence of serotonin with bovine luteal tissue suggests a physiological role for serotonin as an intraovarian regulator of luteal function. 
Scientific Contribution No. 1456 from the New Hampshire Agricultural Experiment Station. We thank Dr G. D. Niswender for the progesterone antiserum, and D. Stranger and M. Coburn for manuscript preparation. This research was a contribution to Northeast Regional Project NE-72.

\section{References}

Aguado, L.I. \& Ojeda, S.R. (1984) Ovarian adrenergic nerves play a role in maintaining preovulatory steroid secretion. Endocrinology 114, 1944-1946.

Axelrod, J., Weil-Malherbe, H. \& Tomchick, R. (1959) The physiological disposition of ${ }^{3} \mathrm{H}$-epinephrine and its metabolite metanephrine. J. Pharmacol. exp. Ther. 137, 251-256.

Bahr, J., Kao, L. \& Nalbandov, A.V. (1974) The role of catecholamines and nerves in ovulation. Biol. Reprod. 10, 273-290.

Battista, P.J. \& Condon, W.A. (1986a) Serotonininduced stimulation of progesterone production by cow luteal cells in vitro. J. Reprod. Fert. 76, 231-238.

Battista, P.J. \& Condon, W.A. (1986b) A role for alternative pathway catecholamines in the regulation of steroidogenesis in cow luteal cells. J. Reprod. Fert. 78, $275-280$.

Battista, P.J., Rexroad, C.E., Jr \& Williams, W.F. (1984) Effects of progesterone administration to dairy heifers on sensitivity of corpora lutea to $\mathrm{PGF}_{2} \alpha$ and on plasma LH concentration. Theriogeneology 22, 47-58.

Birnbaumer, L., Yang, P.C., Hunzicker-Dunn, M., Brockaert, J. \& Duran, J.M. (1976) Adenyl cyclase activities in ovarian tissues. I. Homogenization and conditions of assay in Graffian follicles and corpora lutea of rabbits, rats and pigs: regulation by ATP, and some comparative properties. Endocrinology 99, 163-184.

Blake, C.A. (1976) Effects of intravenous infusion of catecholamines on rat plasma luteinizing hormone and prolactin concentrations. Endocrinology 98, 99-104.

Bolt, D.J. \& Rollins, R. (1976) Increased plasma progesterone during infusion of epinephrine, norepinephrine or isoproterenol in luteal phase ewes. Biol. Reprod., Suppl. 1, Abstr. 43.

Burden, H.W. (1978) Ovarian innervation. In The Vertebrate Ovary, pp. 615-638. Ed. R. E. Jones. Plenum Press, New York.

Burden, H.W. \& Lawrence, I.E. (1977) The effects of denervation on the localization of $\Delta^{5}-3 \beta$-hydroxysteroid dehydrogenase activity in the rat ovary during pregnancy. Acta anat. 97, 286-290.

Casper, R.F. \& Cotterell, M.A. (1984) The effect of adrenergic and cholinergic agents on progesterone production by human corpus luteum in vitro. Am. J. Obstet. Gynecol. 148, 663-669.

Condon, W.A. \& Black, D.L. (1976) Catecholamineinduced stimulation of progesterone by the bovine corpus luteum in vitro. Biol. Reprod. 15, 573-578.

Csapo, A.I. \& Herczeg, J. (1977) Arrest of premature labor by isosuprine. Am. J. Obstet. Gynecol. 129, $482-491$.

Douglas, W.W. (1970) Histamine and antihistamine; 5-hydroxytryptamine and antagonists. In The Pharmacological Basis of Therapeutics, 4th edn, pp. 645-662. Eds L. S. Goodman \& A. Gilman. Macmillan Co., New York.

Ellis, L.C., Jaussi, A.W., Baptista, M.H. \& Urry, R.L. (1972) Correlation of age changes in monoamine oxidase activity and androgen synthesis by rat testicular minced and teased-tubular preparation in vitro. Endocrinology 90, 1610-1618.

Flint, A.P.F., Anderson, A.B.M. \& Turnbull, A.C. (1974) Control of utero-ovarian and peripheral venous plasma progesterone by $\beta$-sympathomimic drugs in pregnant sheep. J. Endocr. 63, 253-254.

Fylling, P. (1971a) Vasopressin-induced increase in peripheral plasma progesterone levels during early human pregnancy. Acta endocr., Copenh. 66, 273-282.

Fylling, P. (1971b) Propranolol-blockade of vasopressininduced increase in plasma progesterone in early human pregnancy. Acta endocr., Copenh. 66, 283-288.

Gadsby, J.E., Keyes, P.L., Schwartz, T.S., Bill, C.H., II \& Lucchesi, B. (1985) Do catecholamines play a physiological role in regulating corpus luteum function in the pseudopregnant rabbit? Biol. Reprod. 32, 907-915.

Godkin, J.D., Black, D.L. \& Duby, R.T. (1977) Stimulation of cyclic AMP and progesterone synthesis by $\mathrm{LH}, \mathrm{PGE}_{2}$ and isoproterenol in the bovine $\mathrm{CL}$ in vitro. Biol. Reprod. 17, 514-518.

Harwood, J.P., Richert, N.D., Dufau, M.L. \& Catt, J.C. (1980) Gonadotropin-induced desensitization of epinephrine action in the luteinized rat ovary. Endocrinology 107, 280-288.

Hsueh, A.J.W., Jones, P.B.C., Adashi, E.Y., Wang, C., Zhuang, L.Z. \& Welsh T.H., Jr (1983) Intraovarian mechanisms in the hormonal control of granulosa cell differentiation in rats. $J$. Reprod. Fert. 69, $325-342$.

Jordan, A.W., III, Caffrey, J.L. \& Niswender, G.D. (1978) Catecholamine-induced stimulation of progesterone and adenosine $3^{\prime}, 5^{\prime}$-monophosphate production by dispersed ovine luteal cells. Endocrinology 103, 385-392.

Kamberi, I.A. \& McCann, S.M. (1969) Effect of biogenic amines, FSH-releasing factors (FRF) and other substances on the release of FSH by pituitaries incubatec in vitro. Endocrinology 85, 815-824.

Kamberi, I.A., Mical, R.S. \& Porter, J.C. (1970) Effects of anterior pituitary perfusion and intraventricular injection of catecholamines on LH release. Endocrinology 87, 1-12.

Kawakami, M., Kubo, K., Uemura, T., Nagase, M. \& Hayashi, R. (1981) Involvement of ovarian innervation in steroid secretion. Endocrinology 109, 136-145. 
Milvae, R.A., Alila, H.W. \& Hansel, W. (1983) Methylation in bovine luteal cells as a regulator of luteinizing hormone action. Biol. Reprod. 29, 849-855.

Niswender, G.D., Reichert, L.E., Jr, Midgley, A.R., Jr \& Nalbandov, A.V. (1969) Radioimmunoassay for bovine and ovine luteinizing hormone. Endocrinology 84, 1166-1173.

Norjavaara, E., Selstam, G. \& Ahren, K. (1982) Catecholamine stimulation of cyclic AMP and progesterone production in rat corpora lutea of different ages. Acta endocr., Copenh. 100, 613-622.

Norjavaara, E., Selstam, G., Damber, J.E. \& Johansson, B.M. (1983) In vivo effect of noradrenaline on the cyclic AMP level in rat corpora lutea. Acta physiol., scand. 119, 113-116.

Perkins, S.N., Cronin, M.J. \& Veldhuis, J.D. (1986) Properties of $\beta$-adrenergic receptors on porcine corpora lutea and granulosa cells. Endocrinology 118, 998-1005.

Ratner, A., Sanborn, C.R. \& Weiss, G.K. (1980) $\beta$ adrenergic stimulation of cAMP and progesterone in rat ovarian tissue. Am. J. Physiol. 239, E139-E143.

Richardson, M.C. \& Masson, G.M. (1980) Progesterone production by dispersed cells from human corpus luteum: stimulation by gonadotrophins and prostaglandin $F_{2} \alpha$ lack of response to adrenaline and isoprenaline. J. Endocr. 87, 247-254.
Schneider, H.P.G. \& McCann, S.M. (1969) Possible role of dopamine as transmitter to promote discharge of LH-releasing factor. Endocrinology 85, 121-132.

Stefenson, A., Owman, Ch., Sjoberg, N.O., Sorrong, B. \& Walles, B. (1981) Comparative study of the autonomic innervation of the mammalian ovary, with particular regard to the follicular system. Cell Tissue Res. 215, 47-62.

Verhofstad, A.A.J. \& Jonsson, G. (1983) Immunohistochemical and neurochemical evidence for the presence of serotonin in the adrenal medulla of the rat. Neuroscience 10, 1443-1453.

Weiss, G.K., Dail, W.G. \& Ratner, A. (1982) Evidence for direct neural control of ovarian steroidogenesis in rats. J. Reprod. Fert. 65, 507-511.

Zsolnai, B., Varga, B. \& Horvath, E. (1982) Increase of ovarian progesterone secretion by $\boldsymbol{\beta}_{2}$-adrenergic stimulation in oestrous rats. Acta endocr., Copenh. $101,268-272$.

Received 21 October 1986 